\section{Antioxidant enzyme activity and physiological potential of Capsicum baccatum var. baccatum seeds as a function of post-harvest storage of fruit}

\author{
Daniel Teixeira Pinheiro ${ }^{1^{*}}$ (D) Rafael Macedo de Oliveira $^{1}$ (iD) Alice de Souza \\ Silveira ${ }^{1}$, Manuel Jesús Zavala León ${ }^{1}{ }^{1}$, Laryssa Bitencourt Teixeira Lima \\ Brum $^{1}\left(\mathbb{D}\right.$, Denise Cunha Fernandes dos Santos Dias ${ }^{1} \mathbb{D}$
}

ABSTRACT: Post-harvest storage of fleshy fruit is a strategy used for improving seed quality. The aim of this study was to evaluate post-harvest storage of the fruit of $C$. baccatum var. baccatum (cumari pepper) and relate it to antioxidant enzyme activity and seed physiological potential. Red-colored fruit ( 65 days after anthesis) was gathered and stored at $20^{\circ} \mathrm{C}$ for $0,5,10,15$, and 20 days. The seeds were removed and evaluated for moisture content, physiological quality, antioxidant enzyme activity, and protein content. The means were fitted to regression equations and then passed through multivariate analysis (PCA). Seed moisture and 100-seed weight decreased through postharvest storage. The 5 - and 10-days storage periods led to an increase in the germination. Electrical conductivity was greater for the 0 - and 20-day storage periods. Dry matter and protein increased in the 5- and 10-days. Enzymes exhibited reductions of activity comparing 0 and 20 days. The post-harvest storage of $C$. baccatum fruit for 5 and 10 days improves seed physiological potential and is related to physiological maturity. The incomplete maturation of cumari seeds obtained from unstored fruit ( 0 days) is related to greater enzyme activity, greater oxidative stress, and low germination and vigor. The lack of post-harvest storage of fruit and storage of fruit for longer than 10 days contributes to a lower physiological potential of cumari pepper seeds.

Index terms: germination, oxygen reactive species, cumari pepper, physiological quality, vigor.

\section{Ação enzimática antioxidativa e potencial fisiológico de sementes de Capsicum baccatum var. baccatum em função do armazenamento pós- colheita dos frutos}

RESUMO: O armazenamento pós-colheita de frutos carnosos é uma estratégia usada para melhorar a qualidade das sementes. $\mathrm{O}$ objetivo deste estudo foi avaliar o armazenamento pós-colheita de frutos de C. baccatum var. baccatum (pimenta cumari) e relacioná-lo à atividade de enzimas antioxidantes e ao potencial fisiológico das sementes. Frutos de cor vermelha (65 dias após a antese) foram colhidos e armazenados a $20^{\circ} \mathrm{C}$ por $0,5,10,15$ e 20 dias. As sementes foram removidas e avaliadas quanto ao grau de umidade, qualidade fisiológica, atividade de enzimas antioxidantes e conteúdo de proteínas. As médias foram ajustadas às equações de regressão e depois avaliadas por análise multivariada (PCA). A umidade e o peso de 100 sementes diminuíram com o armazenamento pós-colheita. Os períodos de armazenamento de 5 e 10 dias levaram a um aumento na germinação. A condutividade elétrica foi maior nos períodos de armazenamento de 0 e 20 dias. A matéria seca e o teor de proteína aumentaram aos 5 e 10 dias. As enzimas exibiram reduções de atividade comparando 0 e 20 dias. 0 armazenamento pós-colheita de frutos de $C$. baccatum por 5 e 10 dias melhora o potencial fisiológico das sementes e está relacionado à maturidade fisiológica. A maturação incompleta de sementes de cumari obtidas a partir de frutos não armazenados (0 dias), está relacionada a maior atividade enzimática, maior estresse oxidativo e baixa germinação e vigor. O não armazenamento pós-colheita dos frutos e o armazenamento por mais de 10 dias contribui para o menor potencial fisiológico de sementes de pimenta cumari.

Termos para indexação: germinação, espécies reativas de oxigênio, pimenta cumari, qualidade fisiológica, vigor.
Journal of Seed Science, v.42, e202042028, 2020

http://dx.doi.org/10.1590/ 2317-1545v42235315 


\section{INTRODUCTION}

Worldwide production of peppers has continued to grow, reaching approximately 40 million tons (FAOSTAT, 2019). Among the pepper genera, Capsicum has around 35 species with color, pungency, and aroma traits that promote human consumption (Carrizo-García et al., 2016; Aguiar et al., 2018). In addition, the species of this genus have notable levels of capsaicinoids, which are secondary metabolites that give rise to the pungency of these species, offer diverse benefits for health, and have industrial applications (Naves et al., 2019). Among the species of the Capsicum genus, C. baccatum var. baccatum, known in Brazil as "cumari", has small, upright, rounded fruit with a mild aroma and high pungency. These traits make it a good option for producing preserves (EPAMIG, 2006).

Germination and vigor are important characteristics for seed-propagated species, for which uniform stand is indispensable for obtaining satisfactory production (Rajjou et al., 2012). In general, peppers are propagated by seeds that have irregular germination, mainly due to dormancy (Quintero et al., 2018), which is a characteristic from its evolutionary development and intrinsic to the genotype. In that regard, post-harvest storage of fleshy fruit is a strategy adopted by producers for the purpose of making the maturity stage more uniform and, in many cases, it can assist in improving the quality and/or breaking the dormancy of seeds in many crops. Recently, many studies report the beneficial effect of post-harvest storage of fruit on the quality of different pepper species (Araújo et al., 2018; Gonçalves et al., 2018; Martínez-Muñoz et al., 2019; Medeiros et al., 2020).

When observed, the deleterious effects of fruit storage are mainly related to seed deterioration, which intensifies after seed physiological maturity (Shaban, 2013). The deterioration process of seeds under different conditions is directly related to incomplete or partial reduction in oxygen, leading to the formation of reactive oxygen species (ROS), such as the superoxide radical $\left(\mathrm{O}^{\circ}\right)$, hydrogen peroxide $\left(\mathrm{H}_{2} \mathrm{O}_{2}\right)$, and the hydroxyl radical $\left(\mathrm{OH}^{-}\right)$(Gupta et al., 2015). Although ROS perform important cell functions, when they are above basal levels, they cause damage that can lead to cell death through oxidative stress (Choudhury et al., 2017). With the aim of neutralizing the deleterious effects of excess ROS on cells, antioxidant mechanisms should be regulated, above all in the seed embryo (Oracz and Karpinski, 2016). In this respect, enzymes such as superoxide dismutase (SOD), catalase (CAT), peroxidase (POX), and ascorbate peroxidase (APX) are part of the enzymatic antioxidant system and play a crucial role in neutralization of these ROS (Kapoor et al., 2019).

Evaluation of antioxidant enzyme activity can provide important responses regarding seed physiological potential under different conditions. Araújo et al. (2018) evaluated antioxidant enzyme activity in $C$. chinense and $C$. frutescens pepper seeds in different maturity groups and observed that CAT showed considerable potential for monitoring seed physiological quality. In C. annum seedlings, high correlation was observed between SOD activity and tolerance to water deficit (Sahitya et al., 2018). Vidigal et al. (2009) observed that SOD enzyme had greater activity in seeds obtained from fruit in more advanced maturity stages of $C$. annum.

Information regarding the effect of post-harvest storage of fruit on antioxidant enzyme activity and its relation to physiological potential in C. baccatum var. baccatum seeds is very limited. Such information may assist in defining strategies regarding adequate management of fruit after harvest for the purpose of obtaining better quality seeds. In light of the above, the aim of this study was to evaluate the effect of post-harvest storage of fruit on the physiological potential and antioxidant activity of $C$. baccatum var. baccatum seeds.

\section{MATERIAL AND METHODS}

The experiment was conducted in the Department of Plant Science of the Universidade Federal de Viçosa, Minas Gerais, Brazil. C. baccatum var. baccatum ("cumari verdadeira") plants were produced in a greenhouse and grown according to recommendations for production of pepper seeds.

Gather and storage of fruits: Ripe fruit was gathered from 20 different plants when it reached intense red coloring, corresponding to approximately 65 days after anthesis. The fruit was stored in kraft paper bags and kept in a laboratory 
environment $\left(20 \pm 2{ }^{\circ} \mathrm{C} ; 60 \%\right.$ relative humidity) for $5,10,15$, and 20 days, which constituted the post-harvest storage treatments. For the control treatment (without storage; 0 days), the seeds were immediately removed from the fruit after it was gathered (Figure 1).

After each storage period, the fruit was cut with a utility knife; the seeds were removed, washed in running water for five minutes, and placed to dry at ambient temperature until reaching approximately $15 \%$ moisture. The following analyses were made:

Moisture content: This was determined immediately after removal of the seeds from the fruit (without washing in running water). The seeds were dried by the laboratory oven method at $105 \pm 3{ }^{\circ} \mathrm{C}$ for 24 hours. Four replications of 50 seeds were used, and the results were expressed in \% (Brasil, 2009).

100-seed weight: Eight replications of 100 seeds were weighed in a precision balance and the results were expressed in grams (g) (Brasil, 2009).

Electrical conductivity: Seeds were dried in the shade until reaching constant weight. After this period, four replications of 50 seeds previously weighed and immersed in $50 \mathrm{~mL}$ of distilled water for 24 hours at $25^{\circ} \mathrm{C}$ (Brasil, 2009). Posteriorly, electrical conductivity was read on a digital conductivity meter, and the results were expressed in $\mu \mathrm{S} . \mathrm{cm}^{-1} \cdot \mathrm{g}^{-1}$.

Germination: Four replications were made of 50 seeds distributed on two sheets of paper towel, moistened with water in the amount of 2.5 times the weight of the dry paper, in "gerbox" boxes. The boxes were kept in BOD with temperatures alternating between $20^{\circ} \mathrm{C}$ and $30^{\circ} \mathrm{C}$ and $8 \mathrm{~h}$ photoperiod; the lighted period corresponded to the higher temperature (Brasil, 2009). After preliminary tests were performed, the time of 30 days was defined for evaluation of germination, and the results were expressed in percentage of normal seedlings.

First germination count: This was performed together with the germination test, evaluating the percentage of normal seedlings obtained 14 days after sowing.

Seed dry matter: Four replications of 50 seeds were weighed and then placed to dry at $105^{\circ} \mathrm{C}$ for $24 \mathrm{~h}$ and weighed once more. The difference between wet weight and dry weight was defined as the seed dry matter content. The results were expressed in g.seeds ${ }^{-1}$.

Antioxidant enzyme activity: The seeds were kept in moistened paper for $48 \mathrm{~h}$ at $20-30{ }^{\circ} \mathrm{C}$. After that, they were frozen in liquid nitrogen and stored at $-20{ }^{\circ} \mathrm{C}$ until the time of evaluation. The activity of the enzymes superoxide dismutase (SOD), catalase (CAT), ascorbate peroxidase (APX) and peroxidase (POX) were determined through crude enzyme extracts, which were obtained by maceration of $0.2 \mathrm{~g}$ of seeds in liquid nitrogen, followed by addition of $2 \mathrm{~mL}$ of extraction medium, potassium phosphate buffer (0.1 M, pH 6.8), containing ethylenediamine tetraacetic acid (EDTA) (0.1 mM), phenylmethylsulfonyl fluoride (PMSF) $(1.0 \mathrm{mM})$, and 1\% polyvinylpolypyrrolidone (PVPP) (w/v) (Peixoto et al., 1999). The homogenate was centrifuged at $14.000 \mathrm{rpm}$ for $15 \mathrm{~min}$ at $4{ }^{\circ} \mathrm{C}$.

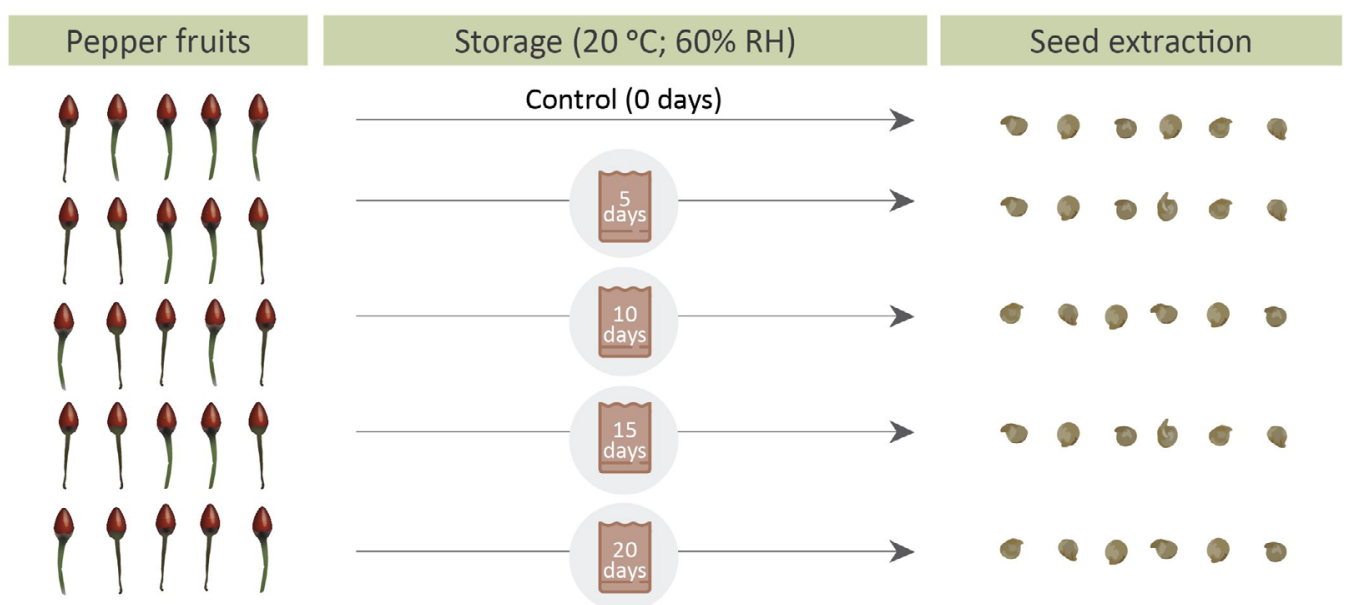

Figure 1. Fruit storage and seed extraction of $C$. baccatum var. baccatum. 
The SOD activity was evaluated by the addition of the crude enzyme extract to $50 \mathrm{mM}$ sodium phosphate buffer (pH 7.8), $13 \mathrm{mM}$ methionine, $75 \mu \mathrm{M}$ nitro blue tetrazolium (NBT), $0.1 \mathrm{mM}$ EDTA, and $2 \mu \mathrm{M}$ riboflavin (Del Longo et al., 1993). The nitroblue tetrazolium (NBT) photoreduction, according to Giannopolitis and Ries (1977). One unit of SOD was defined as the amount of enzyme required to inhibit NBT reduction by $50 \%$ (Beauchamp and Fridovich, 1971). The CAT activity was determined by incubating $50 \mathrm{mM}$ potassium phosphate buffer $(\mathrm{pH} 7.0)$ and $12.5 \mathrm{mM}$ $\mathrm{H}_{2} \mathrm{O}_{2}$ (Havir and McHale, 1987). The enzyme activity was calculated using the molar extinction coefficient of $36 \mathrm{M}^{-1}$.

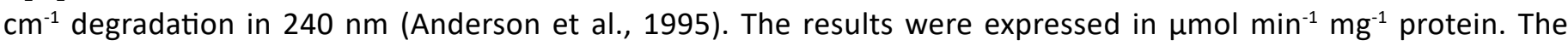
APX activity was determined by incubating $50 \mathrm{mM}$ potassium phosphate buffer ( $\mathrm{pH} 7.8$ ), $0.5 \mathrm{mM}$ ascorbic acid, 0.1 mM EDTA, and $1.2 \mathrm{mM} \mathrm{H}_{2} \mathrm{O}_{2}$. The enzyme activity was calculated using the molar extinction coefficient of $2.8 \mathrm{mM}^{-1}$. $\mathrm{cm}^{-1}$ at $290 \mathrm{~nm}$ (Nakano and Asada, 1981). The results were expressed in nmol. $\mathrm{min}^{-1} \cdot \mathrm{mg}^{-1}$ protein. The POX activity was assessed by the addition by incubating $25 \mathrm{mM}$ potassium phosphate buffer ( $\mathrm{pH}$ 6.8), $20 \mathrm{mM}$ pyrogallol, and 20 $\mathrm{mM} \mathrm{H}_{2} \mathrm{O}_{2}$ (adapted from Kar and Mishra, 1976). Purpurogallin production was measured using the molar extinction coefficient of $2.47 \mathrm{M}^{-1} . \mathrm{cm}^{-1}$ at $420 \mathrm{~nm}$ (Chance and Maehly, 1955).

Protein content: This was determined using bovine serum albumin (BSA) as a standard (Bradford, 1976). Enzyme extract in the amount of $50 \mu \mathrm{L}$ was added to $1 \mathrm{~mL}$ of Bradford reagent, followed by shaking. After 20 minutes, absorbance of the sample was read in a spectrophotometer at $595 \mathrm{~nm}$. The results were expressed in mg.g ${ }^{-1}$ of fresh matter.

Experimental design and statistical analysis: The experiment was conducted in a completely randomized experimental design, with four replications. The data passed through analysis of variance. The mean values obtained for each treatment were fitted to regression equations, and the regression coefficients were evaluated by the $t$-test at $5 \%$ probability. Multivariate principal component analysis (PCA) was performed for all the characteristics evaluated. $A$ " $n \times p$ " matrix was obtained, where " $n$ " corresponds to the number of treatments $(n=5)$ and " $p$ " is the number of variables analyzed $(p=11)$. The eigenvalues and eigenvectors were calculated from the covariance matrices and displayed on a biplot generated from the Factoextra package (Kassambara and Mundt, 2016). The R statistical software was used in all the analyses (R Core Team, 2019).

\section{RESULTS AND DISCUSSION}

Post-harvest storage of the fruit caused gradual reduction in the moisture content of $C$. baccatum var. baccatum seeds. Comparing the control treatment ( 0 days of storage) with the longest period of storage ( 20 days), this reduction was approximately 20 percentage points (p.p.) (Figure $2 \mathrm{~A}$ ).

During the seed maturation process, the moisture content is high and it decreases as seeds complete their development (Marcos-Filho, 2016). The reduction in moisture content leads to multiple changes in the seeds, including transcriptional, post-transcriptional, and metabolic processes (Angelovici et al., 2010). As seeds mature (and dries) their content of ABA often declines, especially in non-dormant seeds, as does the sensitivity of the seed to the hormone, thus permitting germination upon imbibition of the mature seed (Bewley and Nonogaki, 2017). In this context, abscisic acid ( $A B A$ ) has been proved to play a leading role in the regulation of seed maturation, being the balance of this hormone with gibberellic acid (GA) considered the key for seed germination through the dormancy breaking, enzymatic activation, mobilization and transport of reserves, and others (Yan and Chen, 2016; Bewley and Nonogaki, 2017).

Just as for moisture content, there was a reduction in 100-seed weight over the fruit post-harvest storage time. The difference in weight between the seeds obtained from the unstored fruit (0-days) and those stored for 20 days was approximately $1 \mathrm{~g}$. The seeds obtained from fruit stored for 5 days had the maximum 100-seed weight among all the treatments, at approximately $2.4 \mathrm{~g}$ (Figure $2 \mathrm{~B}$ ). Nevertheless, it is important to highlight that both for moisture content (Figure 2A) and for 100-seed weight (Figure 2B), this reduction was especially more accentuated beginning at 10 days of fruit storage. Therefore, the reduction in the seed weight is clearly related to the loss of water from the storage seeds inside the fruits, which is commonly observed in different pepper species (Vidigal et al., 2009; Ricci et al., 2013; Pereira et al., 2014; Araújo et al., 2018). 

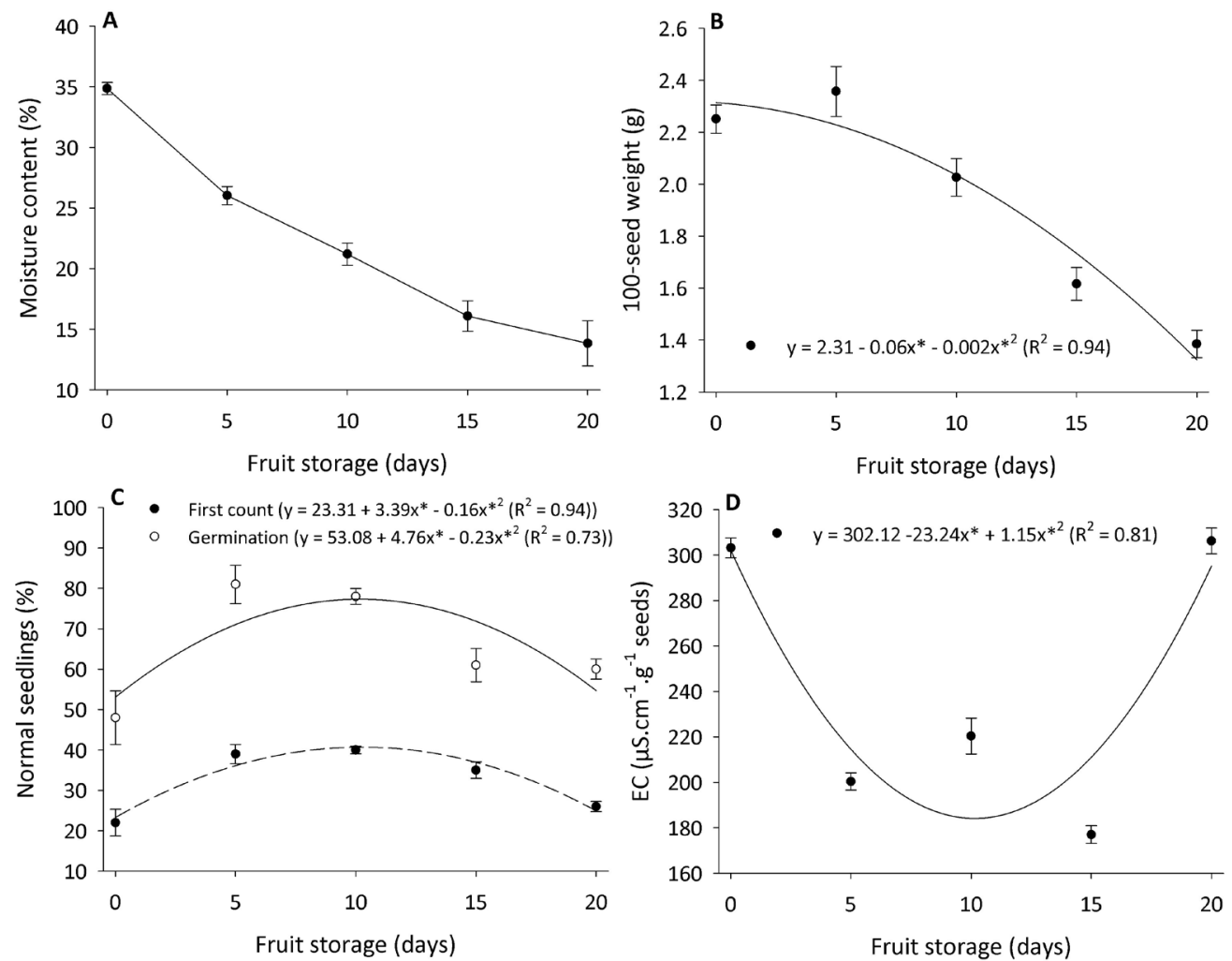

*Significant at $5 \%$ by the $t$-test. Bars: standard deviation.

Figure 2. Moisture content (A), 100-seed weight (B), germination and first germination count (C), and electrical conductivity (D) of $C$. baccatum var. baccatum seeds under different fruit post-harvest storage times.

The first germination count and germination percentage showed a similar quadratic tendency. In general, there was a notable increase in germination up to 10 days of storage and a reduction at 15 and 20 days. The highest percentages of first germination count and germination were observed in the seeds obtained from the fruit stored for 5 days, approximately $39 \%$ and $81 \%$, respectively. In contrast, the lowest percentages of first germination count and germination were obtained in the seeds from the unstored fruit ( 0 days), with values of $22 \%$ and $48 \%$, respectively (Figure 2C). Based on the results of the germination test, it can be said that the seeds of the fruit stored for 5 and 10 days had similar physiological quality. Therefore, the low germination in non-stored fruits ( 0 days) is probably due to dormancy, a common process in pepper species when harvested before the physiological maturity (Queiroz et al., 2011; Ricci et al., 2013; Medeiros et al., 2020). Considering the fruit stored for 20 days, it was observed a similar germination percentage to the seeds of the unstored fruit ( 0 days) (Figure $2 \mathrm{C}$ ). In this context, these results can be associated with the seed deterioration process, which involves many cellular events such as lipid peroxidation, oxidative stress, and mitochondria changes, inducing the reduction of germination and vigor (Ebone et al., 2019).

The seeds obtained from the fruit stored for 5,10 , and 15 days had lower values of electrical conductivity, of approximately 200,220 , and $180 \mu \mathrm{S} . \mathrm{cm}^{-1} \cdot \mathrm{g}^{-1}$, respectively. In contrast, the seeds from fruit stored for 0 and 20 days had higher electrical conductivity, with values of approximately $300 \mu \mathrm{S} . \mathrm{cm}^{-1} \cdot \mathrm{g}^{-1}$ (Figure 2D). The electrical conductivity test is based on organization of cell membranes, and it is directly related to seed physiological quality since higher values indicate lower integrity of cell membranes (Prado et al., 2019). Thus, the electrical conductivity values reinforce the results observed in germination and evidence the lower membrane integrity of the seeds obtained from the unstored fruits ( 0 days) (probably due to the incomplete maturation) and stored for 20 days (due to the seed deterioration). It is important to emphasize that although the 15 day storage time led to a lower conductivity value (Figure 2D), this result 
was not accompanied by high germination rates (Figure $2 \mathrm{C}$ ).

The seed dry matter showed an increase in the treatments of 5 and 10 days in relation to the control ( 0 days), followed by reduction in the treatments of 15 and 20 days. Storage of the fruit for 20 days resulted in the lowest value of seed dry matter (Figure 3A). Just as observed for dry matter, the results observed for protein content help reinforce that physiological maturity was reached between 5 and 10 days of fruit storage, with degradation of these proteins occurring from 15 to 20 days of fruit storage. Comparing the treatments of 10 and 20 days, the difference in protein content was approximately $1 \mathrm{mg} \cdot \mathrm{g}^{-1}$ of fresh matter (Figure 3B).

According to Kijak and Ratajczak (2020), the desiccation tolerance (DT) acquisition in orthodox seeds (such as peppers) is very complex and involves numerous genes encoding proteins involved in gene expression, metabolic shutdown, and storage material accumulation. Among the cellular mechanisms and alterations involved in DT, these authors cite the accumulation of protective late embryogenesis abundant (LEA) and heat shock (HSP) proteins, activation of the antioxidative system, accumulation of sugars, hormonal balance (mainly the degradation of abscisic acid (ABA) and accumulation of gibberellin (GA)), and others. Thus, the sum of these many factors will allow the desiccation, breaking dormancy, storage, and quality maintenance of the seeds (Dekkers and Bentsink, 2015; Kijak and Ratajczak, 2020).

Considering the seed weight, it is a characteristic that can be related to physiological quality, since the stored fruit tends to continue to deposit reserves in the seeds, leading to improvement in physiological quality through the balance between gibberellin (GA) and abscisic acid (ABA). Therefore, based on seed dry matter results, it is possible to confirm the physiological maturity of cumari seeds between 5 and 10 days of fruit storage, evidenced by the maximum dry matter accumulation (Marcos-Filho, 2016). In addition, the deterioration of the seeds stored for 20 days is also reinforced by the lower protein content (Figure 3B), indicating greater consumption of the reserves, affecting germination and vigor under these conditions (Figure 2).

In a similar way, Socolowski et al. (2011) observed that Xylopia aromatica seeds with greater concentrations of proteins manifested a greater speed of germination and formation of normal seedlings. In contrast, the seeds obtained from unstored fruit ( 0 days) also had high levels of protein, but with a low germination percentage, which could be associated with dormancy and greater concentration of ABA (Bewley and Nonogaki, 2017). The ABA is a hormone that directly controls the induction and maintenance of primary seed dormancy through complex crosstalk with other plant hormones, such as GA (Matilla et al., 2015). In this sense, as has been shown in many studies, pepper seeds obtained from recently gathered fruit have lower germination rates compared to seeds from fruit stored after harvest. As already mentioned, this fact is mainly associated with achieving the point of physiological maturity and breaking dormancy as

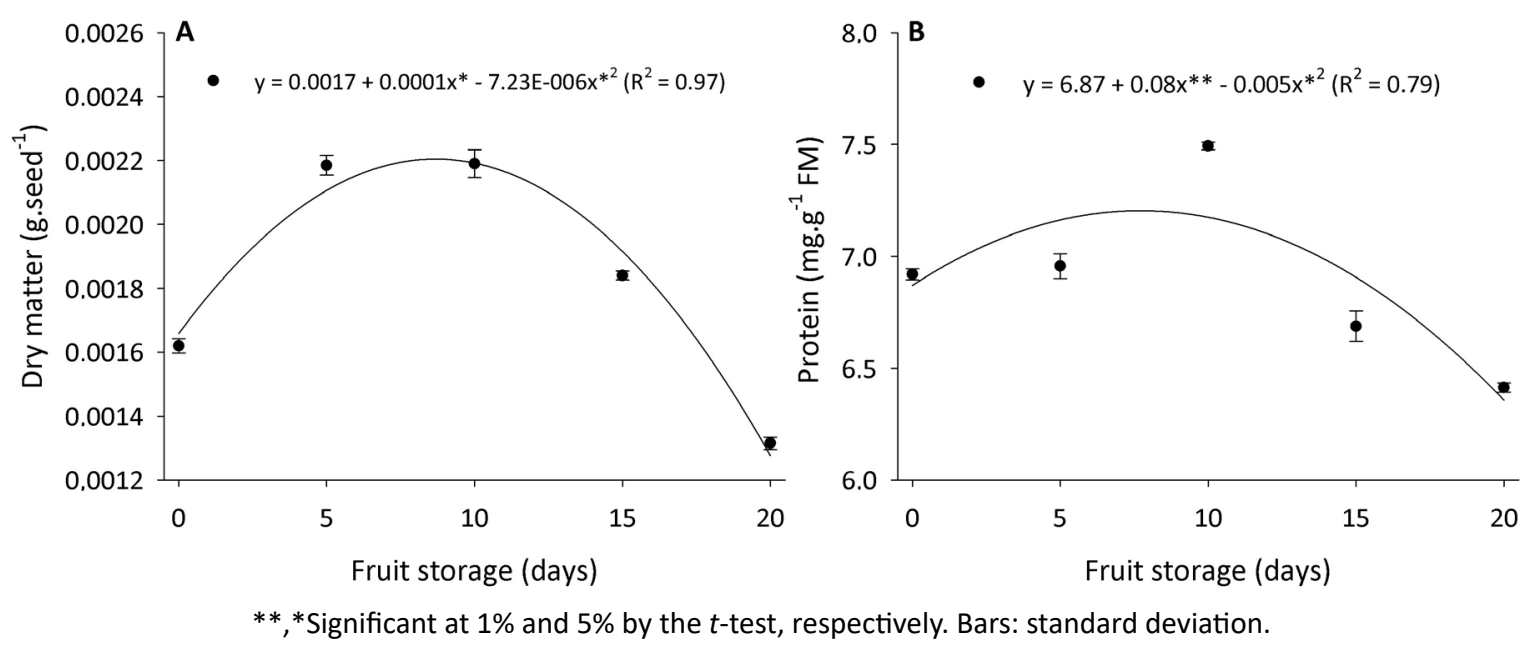

Figure 3. Dry matter (A) and protein content (B) of $C$. baccatum var. baccatum seeds from fruit under different postharvest storage times. 
well as with uniformity of the seed lots (Pereira et al., 2014; Gonçalves et al., 2018; Medeiros et al., 2020).

In summary, the continuous loss of water (Figure $2 \mathrm{~A}$ ) was directly reflected in the reduction in the weight of seeds (Figure 2B) obtained from stored fruit, above all in the seeds obtained from the fruit stored for 20 days. As already mentioned, considering the seeds obtained from the fruit stored for 5 and 10 days, the similarity among these treatments in regard to reduction in moisture content (Figure 2A), 100-seed weight (Figure 2B), germination and first germination count (Figure $2 \mathrm{C}$ ), and electrical conductivity (Figure 2D) may be related to the seed physiological maturity observed in these treatments (Figure 3A).

The deterioration process is directly affected by factors such as genotype and environment (Ellis, 2019), and generally intensifies after the point of seed physiological maturity (Shaban, 2013). Thus, at the time of 20 days of post-harvest fruit storage, there was a reduction in 100-seed weight (Figure 2B) along with a reduction in germination (Figure 2C), an increase in electrical conductivity (Figure 2D), and reduction in dry matter and protein content (Figure 3), confirming an intensification in the deterioration process of the seeds obtained mainly after 10 days of fruit storage.

The post-harvest storage of fleshy fruit is a strategy adopted by producers for the purpose of making seeds more uniform and improving the physiological quality of the seeds after harvest. As also found in this study, C. baccatum seeds obtained from fruit with intense red coloring and kept at rest for 10 days achieved their maximum physiological potential (Pereira et al., 2014; Gonçalves et al., 2018). It is related that $C$. chinenses seeds obtained from yellow and orange fruits exhibit higher physiological quality, as well as low seed dormancy. Furthermore, the storage of yellow and orange fruits after harvested per 7 or 14 days before seed extraction is a good alternative to improve the seed physiological quality of this specie (Medeiros et al., 2020). For C. annum, depending on the level of fruit maturity, storage for 10,14, 15, and up to 20 days contributed to better expression of seed germination and vigor (Alan and Eser, 2008; Vidigal et al., 2009; Martínez-Muñoz et al., 2019). In contrast, C. pubescens seeds removed soon after fruit harvest had better germination and vigor compared to seeds kept in the fruit for up to 17 days. This variation in results shows the wide genetic variability among different species of the Capsicum genus (Keyhaninejad et al., 2014).

Regardless of the antioxidant enzyme evaluated, the greatest activities were observed in the seeds obtained from the unstored fruit ( 0 days), followed by reduction in activity up to 20 days of post-harvest storage of the fruit. These reductions in enzyme activity were generally less accentuated in SOD (Figure $4 \mathrm{~A}$ ) and more accentuated in the enzymes CAT (Figure 4B), APX (Figure 4C), and POX (Figure 4D).

According to Kranner et al. (2010), the response to stresses in seeds can basically be defined as post-translational modifications and signaling of stress through cross-talk between reactive oxygen and nitrogen species and seed hormones, which result in changes in the transcriptome. These authors also mention that when the protection and repair mechanisms fail, depending on the dose and the time of exposure to stress, the result is the death of the seeds. Another important concept to be considered is the "oxidative window for germination", that basically defines the critical levels of ROS threshold. In this sense, when above or below the "oxidative window for germination" (weak or high amounts of ROS), germination cannot occur (Bailly et al., 2008). Therefore, the ROS are related to secondary metabolism and, at high concentrations (upper limit of the oxidative window), they affect cell homeostasis and cause serious damage, especially in lipids, proteins, and nucleic acids (Li et al., 2017). However, at basal concentrations (within the oxidative window), the ROS are considered to be important molecules that act in processes such as cell signaling, gene expression, control of redox status, and, that way, the imbalance between the production of ROS and the antioxidant mechanisms is what in fact characterizes oxidative stress (Bailly et al., 2008; Mittler, 2017; Kapoor et al., 2019). In this context, although the high activity of antioxidative enzymes (indicating the metabolic activation), the unstored seeds ( 0 days) presented low germination and vigor (Figure 2 ). In addition to the probable dormancy of these seeds (as already discussed), these results indicate a level of reactive oxygen species (ROS) in which the enzymes were not able to neutralize. Therefore, greater antioxidant activity, together with lower germination and vigor, could be related to greater oxidative stress in the seeds obtained from the unstored fruit (0 days) (Figure 4). 

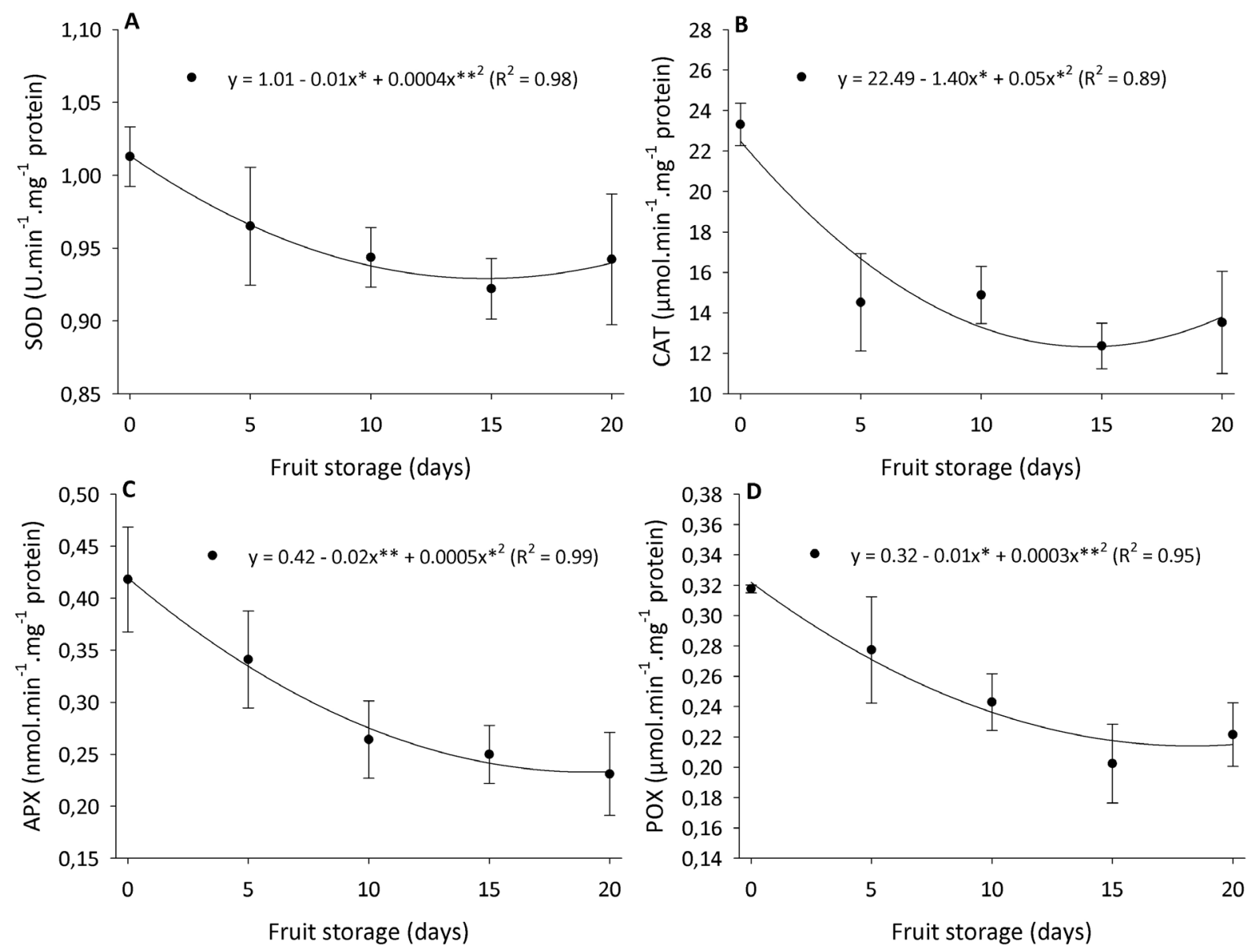

$* *$, Significant at $1 \%$ and $5 \%$ by the $t$-test, respectively. Bars: standard deviation.

Figure 4. Activity of the enzymes superoxide dismutase (SOD) (A), catalase (CAT) (B), ascorbate peroxidase (APX) (C), and peroxidase (POX) (D) in C. baccatum var. baccatum seeds from fruit under different post-harvest storage times.

Moreover, the intermediate antioxidant activity in the seeds obtained from the fruit stored for 5 and 10 days, together with greater germination and vigor, indicate the balance between the ROS and these mechanisms, where the seeds are able to express their maximum physiological potential. In contrast, the low antioxidant activity in the 15- and 20day treatments indicates inefficiency of the antioxidant mechanisms in neutralizing the excess of ROS, with a direct reflection on reduction in germination (Figure 2C), in electrical conductivity (Figure 2D), in dry matter (Figure 3A), and in protein content (Figure 3B) in these treatments. These results are similar to those observed by Araújo et al. (2018) in $C$. frutences and $C$. chinense seeds, where post-harvest storage of the fruit resulted in reduction in CAT activity, which, for its part, was highly related to the physiological quality of the seeds. Another fact that may be related is the significant reduction in moisture content during fruit storage (Figure 2A), especially at 15 and 20 days, which is generally associated with greater ROS production, causing cell damage in seeds during the seed drying process (Bewley and Nonogaki, 2017).

Principal component analysis (PCA) shows that component 1 (PC1) and 2 (PC2) explained 54.4\% and 37.6\%, for a total of $92 \%$ of the total variability of the data (Figure 5). It can be considered efficient for explaining the total variability of the data observed, since the sum of the PC1 and PC2 components was greater than $80 \%$ (Jolliffe and Cadima, 2016).

The treatments corresponding to the seeds obtained from the fruit stored for 5 and 10 days were in the region of the positive scores of $\mathrm{PC} 2$, near the corresponding vectors of first germination count, germination, seed dry matter, and protein content. The treatments corresponding to the seeds from the fruit stored for 15 and 20 days were in the 


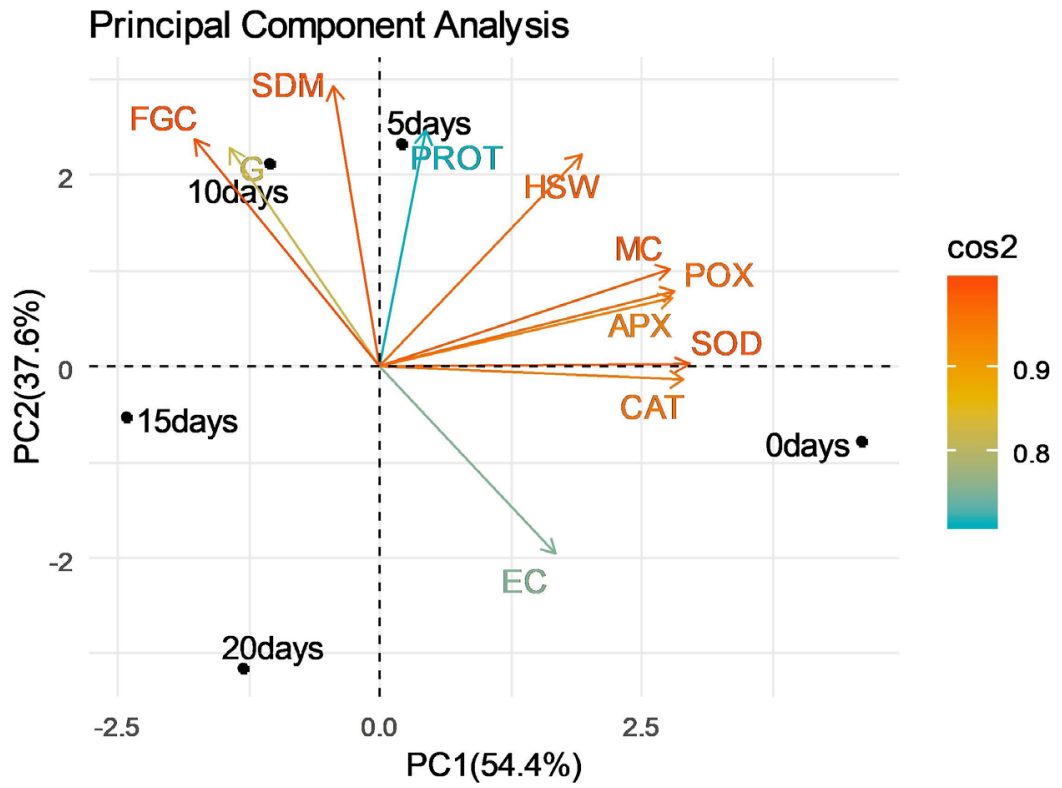

PC1 - Principal component 1; PC2 - Principal component 2; MC - moisture content; HSW - 100-seed weight; EC - electrical conductivity; G - germination; FGC - first germination count; SDM - seed dry matter; PROT - protein content; SOD superoxide dismutase; CAT - catalase; APX - ascorbate peroxidase; and POX - peroxidase.

Figure 5. Biplot obtained from the linear combination of the physiological and biochemical variables in C. baccatum var. baccatum seeds from fruit under different post-harvest storage times.

region of the negative scores of PC2, near the corresponding region of the electrical conductivity vector, indicating lower seed vigor under these conditions. In a similar manner, seeds from the unstored fruit ( 0 days) were also in the region of the negative scores of PC2; however, they were nearer to the vectors corresponding to the antioxidant enzymes. In addition, there is a greater distance of the 20 days treatment from the vectors corresponding to physiological quality and the vectors corresponding to the antioxidant enzymes compared to the other treatments $(0,5,10$, and 15 days) (Figure 5$)$.

In general, the proximity of the vectors of germination, first germination count, dry matter, and protein content of the 5 and 10 days treatments confirm the greater physiological quality of the seeds obtained from these treatments. In contrast, the presence of the 0,15 , and 20 days treatments in the negative scores of the PC2, together with the electrical conductivity vector, show that these conditions (both the lack of storage and storage for more than 10 days) negatively affect the physiological quality of the seeds (Figure 5).

Thus, PCA clearly illustrate the results observed, reinforcing not only the beneficial effects of post-harvest storage of the fruit on the quality of $C$. baccatum var. baccatum seeds, but also the 5 and 10 days times as ideal for this storage. These results can serve as a basis for future studies on $C$. baccatum var. baccatum, such as studies on seed maturation and dormancy, as well as on different conditions of post-harvest storage (such as temperature and relative humidity) of fruit and evaluation of non-enzymatic antioxidant mechanisms.

\section{CONCLUSIONS}

Post-harvest storage of ripe fruit of $C$. baccatum var. baccatum for 5 and 10 days at $20^{\circ} \mathrm{C}$ improves the physiological potential of its seeds and it is also related to their physiological maturity.

The incomplete maturation of cumari pepper seeds obtained from unstored fruits ( 0 days) is related to greater antioxidative enzyme activity, greater oxidative stress, and low germination and vigor.

The lack of post-harvest storage of fruit and storage of fruit for longer than 10 days contribute to reduction in the physiological potential of cumari pepper seeds. 


\section{ACKNOWLEDGMENTS}

Our thanks to the Plant Science Department of the Universidade Federal de Viçosa (UFV). Thanks also to the Conselho Nacional de Desenvolvimento Científico e Tecnológico (CNPq), to the Coordenação de Aperfeiçoamento de Pessoal de Nível Superior (CAPES; Finance Code: 001) and to the Fundação de Amparo à Pesquisa do Estado de Minas Gerais (FAPEMIG) for funding.

\section{REFERENCES}

AGUIAR, A.C.; OSORIO-TOBÓN, J.F.; SILVA, L.P.S.; BARBERO, G.F.; MARTÍNEZ, J. Economic analysis of oleoresin production from malagueta peppers (Capsicum frutescens) by supercritical fluid extraction. The Journal of Supercritical Fluids, v.133, , p.86-93, 2018. https://doi.org/10.1016/j.supflu.2017.09.031

ALAN, Ö.; ESER, B. The effect of fruit maturity and post-harvest ripening on seed quality in hot and conic pepper cultivars. Seed Science and Technology, v.36, n.2, p.467-474, 2008. https://doi.org/10.15258/sst.2008.36.2.21

ANDERSON, M.D.; PRASAD, T.K.; STEWART, C.R. Changes in isozyme profiles of catalase, peroxidase, and glutathione reductase during acclimation to chilling in mesocotyls of maize seedlings. Plant Physiology. v.109, n.4, p.1247-1257, 1995. https://doi. org/10.1104/pp.109.4.1247

ANGELOVICI, R.; GALILI, G.; FERNIE, A.R.; FAIT, A. Seed desiccation: a bridge between maturation and germination. Trends in plant science, v.15, n.4, p.211-218, 2010. https://doi.org/10.1016/j.tplants.2010.01.003

ARAÚJO, R.F.; ABUD, H.F.; SILVA, L.J.D.; ARAÚJO, E.F.; PINTO, C.M.F.; SILVA, F.W.S. Alterações fisiológicas e atividade de enzimas antioxidantes em sementes de pimentas Capsicum chinense Jacq e Capsicum frutescens L. durante o processo de maturação. Revista Ceres, v.65, n.6, p.534-545, 2018. https://doi.org/10.1590/0034-737X201865060009

BAILLY, C.; EL-MAAROUF-BOUTEAU, H.; CORBINEAU, F. From intracellular signaling networks to cell death: the dual role of reactive oxygen species in seed physiology. Comptes Rendus Biologies, v.331, n.10, p.806-814, 2008. https://doi.org/10.1016/j. crvi.2008.07.022

BEAUCHAMP, C.; FRIDOVICH, I. Superoxide dismutase: Improved assays and an assay applicable to acrylamide gels. Analytical Biochemistry, v.44, n.1, p.276-287, 1971. https://doi.org/10.1016/0003-2697(71)90370-8

BEWLEY, J.D.; NONOGAKI, H. Seed Maturation and Germination. Reference Module in Life Sciences. Elsevier. p. 1-9, 2017. https:// www.sciencedirect.com/topics/agricultural-and-biological-sciences/seed-maturation

BRADFORD, M.M. A rapid and sensitive method for the quantitation of microgram quantities of protein utilizing the principle of protein-dye binding. Analytical Biochemistry, v.72, n.1-2, p.248-254, 1976. https://doi.org/10.1016/0003-2697(76)90527-3

BRASIL. Ministério da Agricultura, Pecuária e Abastecimento. Regras para análise de sementes. Ministério da Agricultura, Pecuária e Abastecimento. Secretaria de Defesa Agropecuária. Brasília: MAPA/ACS, 2009. 395p. https://www.abrates.org.br/files/regras_ analise_de_sementes.pdf

CARRIZO-GARCÍA, C.; BARFUSS, M.H.J.; SEHR, E.M.; BARBOZA, G.E.; SAMUEL, R.; MOSCONE, E.A.; EHRENDORFER, F. Phylogenetic relationships, diversification and expansion of chili peppers (Capsicum, Solanaceae). Annals of Botany, v.118, n.1, p.35-51, 2016. https://doi.org/10.1093/aob/mcw079

CHANCE, B.; MAEHLY, A.C. Assay of catalases and peroxidases. Methods in Enzymology, v.2, p.764-775, 1955. https://doi. org/10.1016/S0076-6879(55)02300-8

CHOUDHURY, F.K.; RIVERO, R.M.; BLUMWALD, E.; MITTLER, R. Reactive oxygen species, abiotic stress and stress combination. The Plant Journal, v.90, n.5, p.856-867, 2017. https://doi.org/10.1111/tpj.13299

DEKKERS, B.J.; BENTSINK, L. Regulation of seed dormancy by abscisic acid and delay of germination. Seed Science Research, v.25, n.2, p.82-98, 2015. https://doi.org/10.1017/S0960258514000415 
DEL LONGO, O.T.; GONZÁLEZ, C.A.; PASTORI, G.M.; TRIPPI, V.S. Antioxidant defences under hyperoxygenic and hyperosmotic conditions in leaves of two lines of maize with differential sensitivity to drought. Plant and Cell Physiology, v.34, n.7, p.1023-1028, 1993. https://doi.org/10.1093/oxfordjournals.pcp.a078515

EBONE, L.A.; CAVERZAN, A.; CHAVARRIA, G. Physiologic alterations in orthodox seeds due to deterioration processes. Plant Physiology and Biochemistry, v.145, p.34-42, 2019. https://doi.org/10.1016/j.plaphy.2019.10.028

ELLIS, R.H. Temporal patterns of seed quality development, decline, and timing of maximum quality during seed development and maturation. Seed Science Research, v.29, n.2, p.135-142, 2019. https://doi.org/10.1017/S0960258519000102

EPAMIG. Cultivo da pimenta. Informe Agropecuário, v.27, n.235, 2006. 108 p. http://www.epamig.br/download/informe-agropecuario235-cultivo-da-pimenta-2006/

FAOSTAT. Food and Agriculture Organization of the United Nations. Production quantities of Chillies and peppers, 2019. http://www. fao.org/faostat/en/\#data/QC/visualize

GIANNOPOLITIS, C.N.; RIES, S.K. Superoxide dismutases: I. Occurrence in higher plants. Plant Physiology, v.59, p.309-314, 1977. https://doi.org/10.1104/pp.59.2.309

GONÇALVES, L.S.; GOMES, G.P.; DAMASCENO JUNIOR, C.V.; QUEIROZ, R.A.; TAKAHASHI, L.S.; COSTA, D.S.; NUNES, M.P. Seed physiological potential of "dedo-de-moça" pepper in relation to maturation stages and rest periods of the fruits. Horticultura Brasileira, v.36, n.4, p.486-491, 2018. https://doi.org/10.1590/s0102-053620180410

GUPTA, D.K.; PALMA, J.M.; CORPAS, F.J. Reactive oxygen species and oxidative damage in plants under stress. In: GUPTA, D.K.; PALMA, J.M.; CORPAS, F.J. (Eds.). Heidelberg: Springer International Publishing, 2015. https://link.springer.com/book/10.1007\% 2F978-3-319-20421-5

HAVIR, E. A.; MCHALE, N.A. Biochemical and developmental characterization of multiple forms of catalase in tobacco leaves. Plant Physiology, v.84, n.2, p.450-455, 1987. https://doi.org/10.1104/pp.84.2.450

JOLLIFFE, I.; CADIMA, J. Principal component analysis: a review and recent developments. Philosophical transactions. Series $A$, Mathematical, physical, and engineering sciences, v.374, n.2065, p.20150202, 2016. https://doi.org/10.1098/rsta.2015.0202

KAPOOR, D.; SINGH, S.; KUMAR, V.; ROMERO, R.; PRASAD, R.; SINGH, J. Antioxidant enzymes regulation in plants in reference to reactive oxygen species (ROS) and reactive nitrogen species (RNS). Plant Gene, v.19, 100182, 2019. https://doi.org/10.1016/j. plgene.2019.100182

KAR, M.; MISHRA, D. Catalase, peroxidase, and polyphenoloxidase activities during rice leaf senescence. Plant Physiology, v.57, p.315-319, 1976. https://doi.org/10.1104/pp.57.2.315

KASSAMBARA, A.; MUNDT, F. Factoextra: extract and visualize the results of multivariate data analyses. $R$ Package Version, v.1, n.4, 2016.

KRANNER, I.; MINIBAYEVA, F.V.; BECKETT, R.P.; SEAL, C.E. What is stress? Concepts, definitions and applications in seed science. New Phytologist, v.188, n.3, p.655-673, 2010. https://doi.org/10.1111/j.1469-8137.2010.03461.x

KEYHANINEJAD, N.; CURRY, J.; ROMERO, J.; O'CONNELL, M.A. Fruit specific variability in capsaicinoid accumulation and transcription of structural and regulatory genes in Capsicum fruit. Plant Science, v.215-216, p.59-68, 2014. https://doi.org/10.1016/j. plantsci.2013.10.013

KIJAK, H.; RATAJCZAK, E. What do we know about the genetic basis of seed desiccation tolerance and longevity? International Journal of Molecular Sciences, v.21, n.10, p.3612, 2020. https://doi.org/10.3390/ijms21103612

LI, Y.; WANG, Y.; XUE, H.; PRITCHARD, H.W.; WANG, X. Changes in the mitochondrial protein profile due to ROS eruption during ageing of elm (Ulmus pumila L.) seeds. Plant Physiology and Biochemistry, v.114, p.72-87, 2017. https://doi.org/10.1016/j. plaphy.2017.02.023

MARCOS-FILHO, J. 2016. Seed physiology of cultivated plant. Londrina: ABRATES, 2016. 616 p. 
MARTÍNEZ-MUÑOZ, M.; AYALA-GARAY, Ó.J.; AGUILAR-RINCÓN, V.H.; CONDE-MARTÍNEZ, V.; CORONA-TORRES, T. Seed quality and LEA-protein expression in relation to fruit maturation and post-harvest storage of two chilies types. The Horticulture Journal, v.88, n.2, p.245-252, 2019. https://doi.org/10.2503/hortj.UTD-044

MATILLA, A.J.; CARRILLO-BARRAL, N.; RODRIGUEZ-GACIO, C.M. An update on the role of NCED and CYP707A ABA metabolism genes in seed dormancy induction and the response to after-ripening and nitrate. Journal of Plant Growth Regulation, v.34, n.2, p.274293, 2015. https://doi.org/10.1007/s00344-014-9464-7

MEDEIROS, A.D.; ZAVALA-LEÓN, M.J.; SILVA, L.J.; OLIVEIRA, A.M.S.; DIAS, D.C.F.S. Relationship between internal morphology and physiological quality of pepper seeds during fruit maturation and storage. Agronomy Journal, v.112, n.1, p. 25-35, 2020. https:// doi.org/10.1002/agj2.20071

MITTLER, R. ROS Are Good. Trends in Plant Science, v.22, n.1, p.11-19, 2017. https://doi.org/10.1016/j.tplants.2016.08.002

NAKANO, Y.; ASADA, K. Hydrogen peroxide is scavenged by ascorbate-specific peroxidase in spinach chloroplasts. Plant and Cell Physiology, v.22, n.5, p.867-880, 1981. https://doi.org/10.1093/oxfordjournals.pcp.a076232

NAVES, E.R.; DE ÁVILA SILVA, L.; SULPICE, R.; ARAÚJO, W.L.; NUNES-NESI, A.; PERES, L.E.P.; ZSÖGÖN, A. Capsaicinoids: Pungency beyond Capsicum. Trends in Plant Science, v.24, n.2, p.109-120, 2019. https://doi.org/10.1016/j.tplants.2018.11.001

ORACZ, K.; KARPIŃSKI, S. Phytohormones signaling pathways and ROS involvement in seed germination. Frontiers in Plant Science, v.7, n.864, p.1-6, 2016. https://doi.org/10.3389/fpls.2016.00864

PEIXOTO, P.H.P.; CAMBRAIA, J.; SANT'ANNA, R.; MOSQUIM, P.R.; MOREIRA, M.A. Aluminum effects on lipid peroxidation and on the activities of enzymes of oxidative metabolism in sorghum. Revista Brasileira de Fisiologia Vegetal, v.11, n.3, p.137-143, 1999.

PEREIRA, F.E.C.B.; TORRES, S.B.; SILVA, M.I.L.; GRANGEIRO, L.C.; BENEDITO, C.P. Qualidade fisiológica de sementes de pimenta em função da idade e do tempo de repouso pós-colheita dos frutos. Revista Ciência Agronômica, v.45, n.4, p.737-744, 2014. https:// doi.org/10.1590/S1806-66902014000400011

PRADO, J.P.D.; KRZYZANOWSKI, F.C.; MARTINS, C.C.; VIEIRA, R.D. Physiological potential of soybean seeds and its relationshipto electrical conductivity. Journal of Seed Science, v.41, n.4, p. 407-415, 2019. https://doi.org/10.1590/2317-1545v41n4214988

RICCI, N.; PACHECO, A.C.; CONDE, A.S.; CUSTÓDIO, C.C. Qualidade de sementes de pimenta jalapenho em função da maturação e tempo de permanência nos frutos. Pesquisa Agropecuária Tropical, v.43, n.2, p.123-129, 2013. https://doi.org/10.1590/S198340632013000200008

QUEIROZ, L.A.F.; VON PINHO, E.V.R.; OLIVEIRA, J.A.; FERREIRA, V.D.F.; CARVALHO, B.O.; BUENO, A.C.R. Época de colheita e secagem na qualidade de sementes de pimenta Habanero Yellow. Revista Brasileira de Sementes, v.33, n.3, p.472-481, 2011. http://dx.doi. org/10.1590/S0101-31222011000300010

QUINTERO, C.M.F.; CASTILLO, O.G.; SÁNCHEZ, P.D.; MARÍN-SÁNCHEZ, J.; GUZMÁN, A.I.; SÁNCHEZ, A.; GUZMÁN, J.M. Relieving dormancy and improving germination of Piquín chili pepper (Capsicum annuum var. glabriusculum) by priming techniques. Cogent Food \& Agriculture, v.4, 1550275, 2018. https://doi.org/10.1080/23311932.2018.1550275

R CORE TEAM. R Development Core Team. R: A Language and Environment for Statistical Computing, 2019.

RAJJOU, L.; DUVAL, M.; GALLARDO, K.; CATUSSE, J.; BALLY, J.; JOB, C.; JOB, D. Seed Germination and Vigor. Annual Review of Plant Biology, v.63, p.507-533, 2012. https://doi.org/10.1146/annurev-arplant-042811-105550

SAHITYA, U.L.; KRISHNA, M.S.R.; DEEPTHI, R.; PRASAD, G.S.; KASIM, D. Seed antioxidants interplay with drought stress tolerance indices in Chilli (Capsicum annuum L.) seedlings. BioMed Research International, n.1605096, p.1-14, 2018. https://doi. org/10.1155/2018/1605096

SHABAN, M. Review on physiological aspects of seed deterioration. International Journal of Agriculture and Crop Sciences, v.6, n.11, p.627-631, 2013. https://www.semanticscholar.org/paper/Review-on-physiological-aspects-of-seed-Shaban/2cb1f6fca3e3b $6 \mathrm{~d} 06853033144 \mathrm{db} 43769 \mathrm{~b} 085 \mathrm{a} 9 \mathrm{~b}$

SOCOLOWSKI, F.; CICERO, S.M.; VIEIRA, D.C.M. Seed weight of Xylopia aromatica (Annonaceae): Quality evaluation from X-ray and seedling emergence. Scientia Agricola, v.68, n.6, p.643-646, 2011. https://doi.org/10.1590/S0103-90162011000600006 
VIDIGAL, D.S.; DIAS, D.C.F.S.; VON PINHO, E.R.V.; DIAS, L.A.S. Sweet pepper seed quality and lea-protein activity in relation to fruit maturation and post-harvest storage. Seed Science and Technology, v.37, n.1, p.192-201, 2009. https://doi.org/10.15258/ sst.2009.37.1.21

YAN, A.; CHEN, Z. The pivotal role of abscisic acid signaling during transition from seed maturation to germination. Plant Cell Reports, v.36, n.5, p.689-703. https://link.springer.com/article/10.1007/s00299-016-2082-z 